\title{
Reduction of Greenhouse Gas Emissions of Azolla pinnata Inclusion in Backyard Chicken Production
}

\author{
M. T. M. Espino*(**)† and L. M. Bellotindos*(***) \\ *Engineering Graduate Program, School of Engineering, University of San Carlos, Talamban Campus, Cebu City 6000, \\ Philippines \\ **Department of Industrial Engineering, School of Engineering and Architecture, Ateneo de Davao University, \\ Davao City 8000, Philippines \\ ***Center for Research in Energy Systems and Technologies (CREST), School of Engineering, University of San \\ Carlos, Talamban Campus, Cebu City 6000, Philippines \\ $\dagger$ Corresponding author: M.T.M. Espino; mtmespino@addu.edu.ph
}

Nat. Env. \& Poll. Tech. Website: www.neptjournal.com

Received: 20-01-2020

Revised: 09-02-2020

Accepted: 16-04-2020

Key Words:

Greenhouse gas

Global warming

Azolla pinnata

Protein feed supplement

\begin{abstract}
Backyard chicken production is an integral part among rural families in the tropics like the Philippines. However, it has been declining as it continues to suffer low productivity with its small-scale operations. Among its production inputs, feeds remain to be the top cost driver, as well as the top contributor to greenhouse gas (GHG) emissions that result in global warming potential (GWP). In a prior experiment, $50 \%$ inclusion of Azolla Pinna was recommended in feed ration due to its favourable and comparable growth performance of Dominant DZ backyard chickens. Hence, this study further evaluated the inclusion in terms of environmental performance. The $50 \%$ inclusion resulted in reductions of $\mathrm{CO}_{2}$ by $35 \%, \mathrm{~N}_{2} \mathrm{O}$ by $22.32 \%$, and $\mathrm{CH}_{4}$ by $4.74 \%$. The gross effect of this reduction of conventional feeds is a climate change mitigation equivalent $28.47 \%$ of $\mathrm{GWP} \mathrm{kg} \mathrm{CO}_{2}$-eq./1,000 birds. The potential impacts indicate that Azolla Pinnata can be a cost-effective and sustainable feedstuff in backyard chicken rearing system especially that it requires simple propagation method. The environmental impacts and savings can encourage more livelihood activities in rural.
\end{abstract}

\section{INTRODUCTION}

\section{Backyard Chicken Production}

Despite the soaring modernization of commercial poultry production in the global arena, backyard chicken production continues to be a significant activity in the rural and periurban areas (Padhi 2016). In this set-up, the backyard chickens, which are usually indigenous, native or improved breed, are typically housed in simple night shelters with limited management and disease prevention measures. They are fed a mixture of household food waste and second-grade crops and are supplemented scavenging for opportunistic food sources such as insects and food scraps. This backyard production is traditionally family-based in small scale and is estimated to contribute $4 \%$ of total poultry meat production and $14 \%$ of total eggs production worldwide (MacLeod et al. 2013). For small-scale farmers in developing countries, the family-based poultry represents one of the few opportunities for saving, investment and security against risk. Though it is rarely the sole means of livelihood, it is integrated and complementary to farming activities. It can provide additional income from the sale of birds and eggs, as well as, accessibility to valuable source of protein in the diet (Thieme et al. 2014). However, backyard chicken production has been declining in most countries. Its ability to sustain and achieve the optimal solution to food and nutrition security can only be achieved if constraints, such as inherent low production, diseases, fluctuation in feed prices and access to veterinary services, are properly addressed (Wong et al. 2017).

Just like most rural areas, backyard chicken production in the Philippines is popular. It has been an integral part of the farming systems as a source of chicken meat and eggs. By definition, backyard production comprises of 100 birds of native or improved breeds that are raised primarily for their own consumption in a free-range system of management, which allow birds to forage and look for their food (Sison 2014). The produce of indigenous chicken has been perceived and preferred over the commercial broiler chicken because of taste, leanness and colour, which are more suitable for popular Filipino dishes. With their limited supply, both meat and eggs are priced more than twice the commercial production. 
The top producing provinces in the country are Negros Occidental, Iloilo, Bukidnon, Davao del Sur, and Cebu. As of 2016, the backyard operation with native chicken inventory registered at $78.4 \mathrm{M}$ in 2016 , native breed accounts $44.7 \%$ of total chicken, a significant decline from $54.7 \%$ in 2001 (PSA 2018). The approximately $20 \%$ decline for backyard production can be attributed to the lack of attention and focus given there is little to gain from a very small production base. The decline may continue to progress as the backyard production continue to suffer low productivity and high mortality rates with the limited of technical knowhow and usage of optimal resources and inputs. Moreover, technology improvements are not that welcomed with the limited capital and other resources, and adoption disposition (Chang 2007).

Backyard chickens need essential nutrients such as carbohydrates, proteins, fats and oils, minerals, vitamins, and water to survive, grow, and reproduce. To have a consistent and stable marketable weight, some farms used commercial feeds for feeding to complement the forage and free-range activities of the birds. However, the use of commercial feeds increase the cost of production, thereby, supplemental feeding is more economical (Mananghaya 2017).

In terms of duration, feeding is around 90 days to achieve the taste and leanness of native chicken. This means longer feeding period for backyard chicken to achieve 0.7-1.1 kilo weight in ninety days, versus broiler chicken of 1-1.5 kilo over 28 days (Jaturasitha et al. 2002, Roxas 2000).

\section{Azolla Pinnata Feedstuff}

In any poultry production system, the highest cost driver is feeds, which accounts for about approximately 50 to $70 \%$. The feed can go as high as $75 \%$ of the total cost of production in view of commercial feeds, being the major portion of the variable costs. (Dozier et al. 2008) In the Philippines, the price of commercial feeds will continue to rise. Most of the ingredients are imported such as soybean meal, which is the primary protein source. Various studies have explored the different alternative protein feedstuffs that are abundant in the tropics. One of the promising alternative forages is Azolla Pinnata. It is a floating fern belonging to the family of Azollaceae. The fixation and assimilation of atmospheric nitrogen are generated when it hosts the blue-green algae, Anabaena azollae symbiotically. Hence, it provides the carbon source and favourable environment for the growth and development of the algae (Rascio \& La Rocca 2008). This unique symbiotic relationship makes Azolla, an effective and economical plant with high protein content. It has rich nutritive value, which includes proteins, essential amino acids, vitamins (vitamin A, vitamin B12 and beta-carotene), growth promoter intermediaries and minerals like calcium, phosphorous, potassium, ferrous, copper, magnesium etc. It contains 25 to $35 \%$ protein, 10 to $15 \%$ minerals and $7-10 \%$ amino acids, bio-active substances and bio-polymers. Its nutrient composition makes it a highly efficient and effective feed for livestock, which can be easily digested, with its high protein and low lignin content (Pillai et al. 2005). In Nigeria, the effect of incorporating graded levels of Azolla meal (AZM) in diets of growing pullets was investigated. Particular reference was given to growth, haematology and subsequent laying performance, among 2-week old Nera brown pullets. The results demonstrated a benefit from AZM at a low level of supplementation and up to $15 \%$ AZM can be incorporated in diets of growing pullets without jeopardizing the health and subsequent laying performance (Alalade et al. 2007). In another research, the impact of feeding restricted diets supplemented with free fresh Azolla (as a good source of crude protein and metabolizable energy, and extra essential nutrients as vitamins and minerals) on performance and economic efficiency of Fayoumi growing chicks was evaluated in Egypt. It was concluded that free fresh Azolla could be compensated the restriction diet up to $15 \%$ without any counterproductive effects on the performance and edible parts (carcass and internal organs) of Fayoumi growing chicks until marketing age. Moreover, the Fayoumi chicks on the $45 \%$ restricted diet, plus free fresh azolla achieved the best feed conversion rate and economic efficiency (Namra et al. 2010).

\section{Case Study in the Philippines}

In an experiment of the authors of the growth performance, a Dominant CZ Chicken supplemented with AZM was very promising. It was tested on backyard rearing system to investigate how it can be incorporated as an alternative feeds in a farm with backyard rearing system with a tropical climate in Lamacan, Argao in Cebu Province, Region VII, Philippines. The rations were based on an organic farm that campaigned cutting down commercial feeds by at least $50 \%$ and looking at almost $100 \%$ non-inclusion of commercial feeds in their feeding (PinoyBisnis.com 2010). 27-day old Dominant CZ chicks were used in this study for 90 days. They were randomly grouped to Treatment 1 (T1): control group with $100 \%$ commercial feeds, Treatment 2 (T2): the ration with 50\% commercial feeds and 50\% Azolla; and Treatment 3 (T3): ration with 25\% commercial feeds and $75 \%$ Azolla. The standard management practices, rearing and environmental conditions were the same for all treatments. Feeding was provided in ad libitum during the booster stage. While during the starter and grower stages, feeding followed the feed intake guide used in the farm. The results showed that $\mathrm{T} 2$ and $\mathrm{T} 3$ have satisfactory performance versus $\mathrm{T} 1$ since 
they were able to achieve the marketable weight of 1000 grams in 90 days. The average weight gain of T2 was 1,094.6 grams, which is just $8.2 \%$ lower than the $\mathrm{T} 1$ at $1,194.4$, while T3 was $1,081.2$ or $9.4 \%$ versus T1. The details in growth performance evaluation can be found in Table 1. A separate

a)

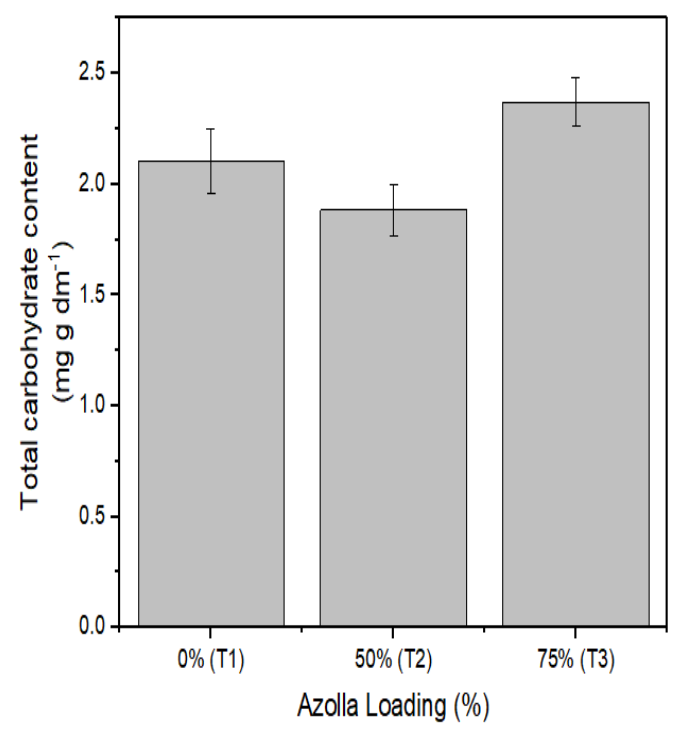

c)

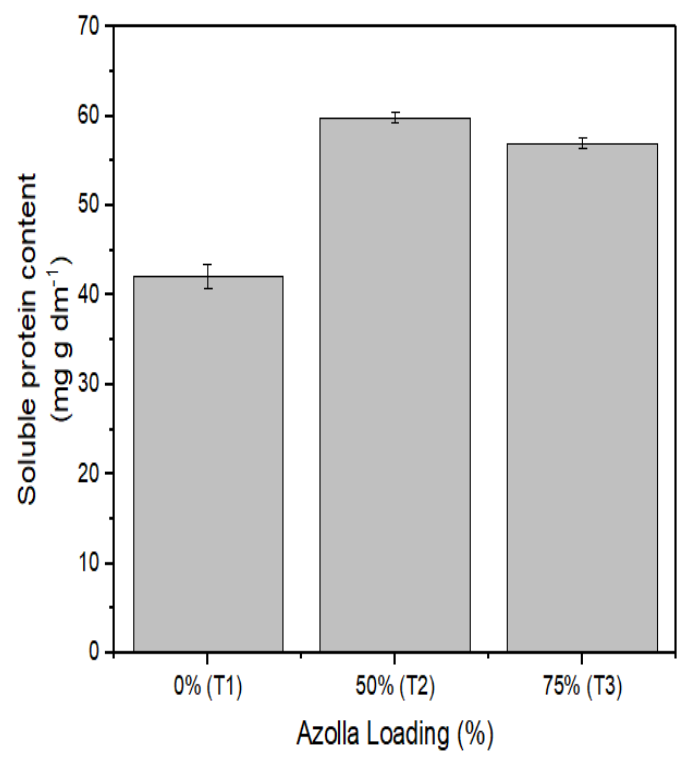

meat chemical composition analysis (Siacor 2019) on total carbohydrate, polyphenol, soluble protein, and proteolytic enzyme activity was done with results in Fig. 1. The results on growth performance and meat quality of the chickens fed with $50 \%$ AZM were favourable.

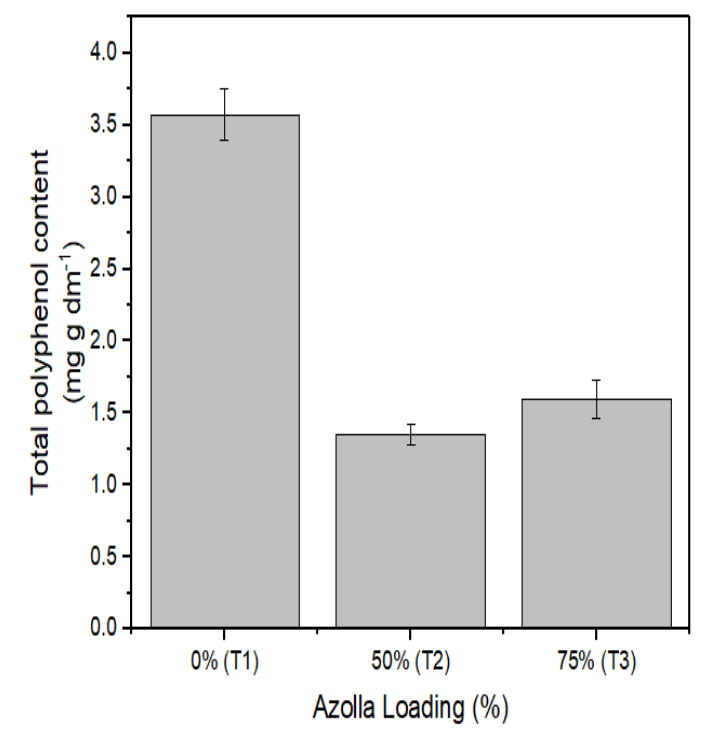

d)

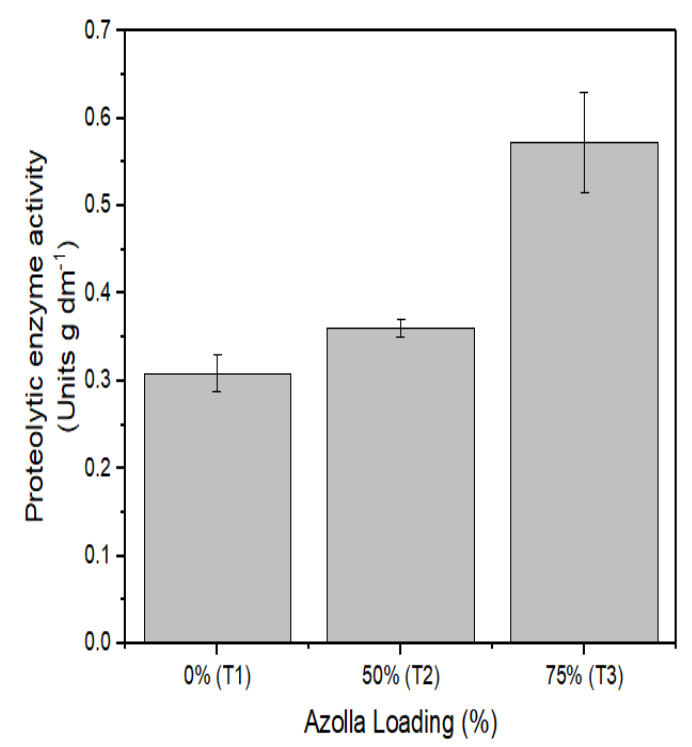

Source: (Siacor,2019)

Fig. 1: Meat Chemical Composition with various Azolla Loading.

a) Total carbohydrate b) polyphenol c) soluble protein d) proteolytic enzyme activity of the chicken carcass at varying levels of Azolla loading in the chicken feed (values represent an average for three replicates; error bars represent standard deviation) 
Table 1: Growth Performance of CZ Chickens at different feeding stages

\begin{tabular}{|c|c|c|c|c|c|}
\hline Attributes & T0 control & T1 50\% Azolla & T2 $75 \%$ Azolla & Mean & SEM \\
\hline \multicolumn{6}{|c|}{ CUMMULATIVE WEIGHT (g) } \\
\hline Initial & 49.62 & 50.51 & 50.59 & 50.23 & 1.12 \\
\hline Booster & 231.21 & 182.89 & 181.05 & 199.05 & 7.83 \\
\hline Starter & 826.57 & 754.09 & 686.06 & 758.25 & 17.84 \\
\hline Grower & $1,244.03$ & $1,145.09$ & $1,131.74$ & $1,175.23$ & 20.75 \\
\hline \multicolumn{6}{|c|}{ WEIGHT GAIN (g) } \\
\hline Booster & $181.59^{\mathrm{a}}$ & $132.38^{\mathrm{a}}$ & $130.46^{\mathrm{a}}$ & 148.82 & 7.72 \\
\hline Starter & $595.36^{\mathrm{a}}$ & $571.20^{\mathrm{b}}$ & $505.01^{\mathrm{ab}}$ & 559.20 & 12.86 \\
\hline Grower & 417.47 & 391.00 & 445.68 & 416.98 & 11.76 \\
\hline Total & $1,194.41^{\mathrm{a}}$ & $1,094.58^{\mathrm{a}}$ & $1,081.15^{\mathrm{a}}$ & $1,125.00$ & 20.85 \\
\hline Ave. Daily & 13.27 & 12.16 & 12.01 & 12.50 & 0.23 \\
\hline \multicolumn{6}{|c|}{ FEED INTAKE (g) } \\
\hline Booster & 320.25 & 310.07 & 295.19 & 308.50 & 8.18 \\
\hline Starter & $1,433.01$ & $1,471.15$ & $1,463.23$ & $1,455.80$ & 7.68 \\
\hline Grower & $2,190.02$ & $2,185.31$ & $2,170.43$ & $2,181.92$ & 7.80 \\
\hline Total & $3,943.28$ & $3,966.53$ & $3,928.85$ & $3,946.22$ & 18.86 \\
\hline Ave daily & 43.81 & 44.07 & 43.65 & 43.85 & 0.21 \\
\hline \multicolumn{6}{|c|}{ CONVERSION RATIO } \\
\hline Booster & 1.76 & 2.34 & 2.26 & 2.27 & 0.11 \\
\hline Starter & $2.41^{\mathrm{a}}$ & $2.58^{\mathrm{b}}$ & $2.90^{\mathrm{ab}}$ & 2.64 & 0.06 \\
\hline Grower & 5.25 & 5.59 & 4.87 & 5.34 & 0.16 \\
\hline Total & $3.30^{\mathrm{a}}$ & $3.62^{\mathrm{a}}$ & $3.63^{\mathrm{a}}$ & 3.54 & 0.06 \\
\hline
\end{tabular}

Mean values within a row with superscripts differ significantly $(\mathrm{p}<0.05)$; Source: (Authors)

\section{Environmental Impacts}

One of the environmental concerns in any producing industry is global warming. It is the average increase in the temperature of the atmosphere near the Earth's surface and in the troposphere, which can contribute to changes in global climate patterns. Global warming can have many different causes, but it is most commonly associated with human interference, specifically the release of excessive amounts of greenhouse gases such as carbon dioxide $\left(\mathrm{CO}_{2}\right)$, methane $\left(\mathrm{CH}_{4}\right)$, water vapour, and fluorinated gases earth (EPA 2017). Based on World Resources Institute Climate Analysis Indicators Tool, the Philippines' total GHG emissions are at 57.6 million metric tons of carbon dioxide equivalent $\left(\mathrm{Mt} \mathrm{CO}_{2} \mathrm{e}\right), 0.33 \%$ of global $\mathrm{GHG}$ emissions. This was dominated by the energy sector (54\%), followed by agriculture (33\%), industrial processes (IP) $(8 \%)$, and waste (7\%). Between 1990-2012, total GHG increased by $54 \mathrm{MtCO}_{2} \mathrm{e}$ or an equivalent of $53 \%$ over the period and an annual change of $2.1 \%$. These were driven by energy (3.4\%), agriculture $(1.5 \%)$, IP $(7.1 \%)$, waste $(2.1 \%)$, and land use change and forestry $(-12.4 \%)$ (USAID 2016). In response to the increasing GHG, the Philippine Climate Change Commission (CCC) (Climate Change Commission 2011) formulated the 2010-2028 National Framework Strategy on Climate Change which identified a long-term mitigation objective of facilitating the transition towards low GHG emissions for sustainable development. CCC outlined the national climate change action plan in 2011. For agriculture, it articulated the following activities: enhance site-specific knowledge on the vulnerability of agriculture and fisheries to the impacts of climate change; conduct researches and disseminate knowledge and technologies on CC adaptation to reduce vulnerability of the sector to climate change; and establish knowledge management on climate change information for agriculture. Moreover, the country committed to reducing its GHG emissions by $70 \%$ by 2030 compared to a business-as-usual scenario through mitigation measures in the energy, transport, waste, forestry, and industry sectors.

Aligned to climate change initiatives, this research aims to answer the following questions: What is the GWP impact of the studied backyard system? and How much GWP impact is reduced with the inclusion of Azolla Pinnata in the ration? 
With the formulated questions, this study aimed to evaluate the potential GWP reduction with the inclusion of AZM.

\section{MATERIALS AND METHODS}

\section{Life Cycle Assessment (LCA)}

This study utilizes the Life Cycle Assessment (LCA), an environmental management tool to evaluate a certain product or process in view of assessing and optimizing the quality of a system, in terms of environmental impacts over its entire life cycle. The concept was introduced by SETAC (Society of Environmental Toxicology and Chemistry) and has become a credible technique in many sustainability and environmental assessment endeavours among policymakers, manufacturers and consumers in planning and decision-making activities (Jensen 2008).

\section{Impact Categories}

The study focuses on Climate Change, the Global Warming Potential based on TRACI 2.1 (the Tool for the Reduction and Assessment of Chemical and other Environmental Impacts). TRACI 2.1 utilizes global warming potentials (GWPs) for the calculation of the potency of greenhouse gases relative to $\mathrm{CO}_{2}$, expressed as $\mathrm{kgCO}_{2}$ /equivalent (Bare 2012). The relevant gases in the analysis are carbon dioxide, methane and nitrous oxide, which are discussed by (EPA 2017) to be as follows.

Carbon dioxide $\left(\mathrm{CO}_{2}\right)$ enters the atmosphere through burning fossil fuels (coal, natural gas, and oil), solid waste, trees and wood products, and also as a result of certain chemical reactions. Carbon dioxide is removed from the atmosphere (or "sequestered") when it is absorbed by plants as part of the biological carbon cycle.

Methane $\left(\mathrm{CH}_{4}\right)$ is emitted during the production and transport of coal, natural gas, and oil. $\mathrm{CH}_{4}$ emissions can also be generated from livestock and other agricultural practices as well as the decay of organic waste in municipal solid waste landfills. One kilogram of $\mathrm{CH}_{4}$ has $25 \mathrm{GWP}$ versus a kilo of carbon dioxide.

Nitrous oxide $\left(\mathrm{N}_{2} \mathrm{O}\right)$ is emitted during agricultural and industrial activities, as well as during combustion of fossil fuels and solid waste. One kilogram of $\mathrm{N}_{2} \mathrm{O}$ has $298 \mathrm{GWP}$ versus a kilo of carbon dioxide

\section{Data Collection}

The data on the material flow included the various inputs and outputs within the system boundaries of the scope of the study farm. The relevant data were collected from interviews of the farm owner, caretaker and observations during the conduct of the feeding trial. The collected data were then classified and established based on their equivalence per gas category. Presented in Table 2 is the summary of GHG factors.

The databases on GHG emissions on transportation, agricultural wastes and biomasses were based from (Engineering Tool Box 2009, EPA 2017). For utilities, from the equivalent carbon footprint of water (Griffiths-Sattenspiel \& Wilson 2009) while electricity from Philippine's national grid emission factor. (DOE, 2017) Lastly, for feed and manure, GLEAM-interactive (GLEAM-i) (FAO 2017) was used. The parameters on the production system, feed formulation, manure management and operational parameters on mortality rates, slaughter weight and manure management were inputted in GLEAM-i to generate the corresponding GHGs of the studied farm. The same system and process were done in establishing the corresponding GHG of feeds and manure for AZM inclusions.

\section{RESULTS AND DISCUSSION}

\section{Material Flow Analysis of the Backyard Chicken Farm}

The boundary and material analyses are shown in Fig. 2 . The farm raises Dominant CZ breed on backyard free-range rearing system. One production cycle is composed of 200 birds in 90 days with 5\% average mortality. The DOCs, weighing an average of 50 grams each, are transported to the farm using a multi-cab from a hatchery in a nearby town,

Table 2: GHG Emission Factors of different inputs used in the Backyard Chicken Farm.

\begin{tabular}{|lllll|}
\hline Inputs & Unit & $\mathrm{CO}_{2}$ & $\mathrm{CH}_{4}$ & $\mathrm{~N}_{2} \mathrm{O}$ \\
\cline { 3 - 5 } & & $\mathrm{kg} /$ Unit & $\mathrm{g} /$ Unit & $\mathrm{g} /$ Unit \\
\hline Transpo-Delivery & $\mathrm{L}$ & 2.3480 & 0.0026 & 0.0011 \\
Transpo-Motorcycle & $\mathrm{L}$ & 2.3190 & 0.0011 & 0.0001 \\
Electricity & $\mathrm{kWh}$ & 0.6030 & & \\
Water & $\mathrm{m}^{3}$ & 0.8700 & & \\
Bedding & $\mathrm{kg}$ & 0.9750 & 0.2640 & 0.0350 \\
Feed & $\mathrm{kg} \mathrm{CW}$ & 1.6853 & - & 4.4760 \\
Manure & $\mathrm{kg} \mathrm{CW}$ & - & 11.3649 & 11.1614 \\
\hline
\end{tabular}


$37.1 \mathrm{~km}$ in distance. To make sure their health and survival, DOCs stay in an area with brooding lights that facilitate the required temperature and humidity. The corresponding required electricity to maintain this artificial brooding is 1 watt per bird. Aside from catching the litters of DOCS, the rice hull bedding also provides the heat necessary for brooding. Approximately $125 \mathrm{~kg}$ of rice hulls is used for both brooding and rearing stages.

After 28 days, the birds are allowed to range. The typical area estimated for free-ranging is $1 \mathrm{sqm}$. per bird. One caretaker is in charge of maintaining the cleanliness of the barn and farm, feeding the birds and pasturing them. The caretaker went to the ranging area twice a day, morning and afternoon for feeding and pasturing. He rode a motorcycle along a distance of approximately $1.5 \mathrm{~km}$ from the owner's place to the farm.

In a 90 day-cycle, one bird can consume 3.9 kilos of commercial feeds, which comprises $8.4 \%$ starter feeds given over 28 days; $37.8 \%$ starter over 35 days; and $53.8 \%$ grower $53.8 \%$ over 27 days. The conventional feeds are commercially available in the market, which is approximately $3 \mathrm{~km}$ from the owner's place. The required feeds are procured every two weeks and are stored at the owner's place. Only the required amount per feeding is brought to the farm. To ensure health and safety, basic recommended vaccines are also provided to the growing chicks.

In terms of water consumption, one bird drinks 0.5 litres per day or a total of 45 litres over the cycle. Minimal water is used in cleaning and up-keeping the barn and farm. Both water and electricity are locally supplied by respective service providers. The average utilities in a cycle are $9.5 \mathrm{~m} 3$ for water and $145.2 \mathrm{kWh}$ for electricity.

At the end of the cycle, the birds have an average live weight of $1.5 \mathrm{~kg}$. They are usually sold live but sometimes are slaughtered at the farm and sold as roasted chicken. The average dressing percentage is $71 \%$, which makes the dressed chicken equivalent to approximately $1 \mathrm{~kg}$.

\section{Environmental Impact}

Life cycle inventory and GHG emissions of current setup: The life cycle inventory and GHG emission, as given in Table 3, were quantified based on 1,000 birds or an equivalent of 5 cycles for easier reference and analysis in this study. The current set-up is an equivalent global warming potential of

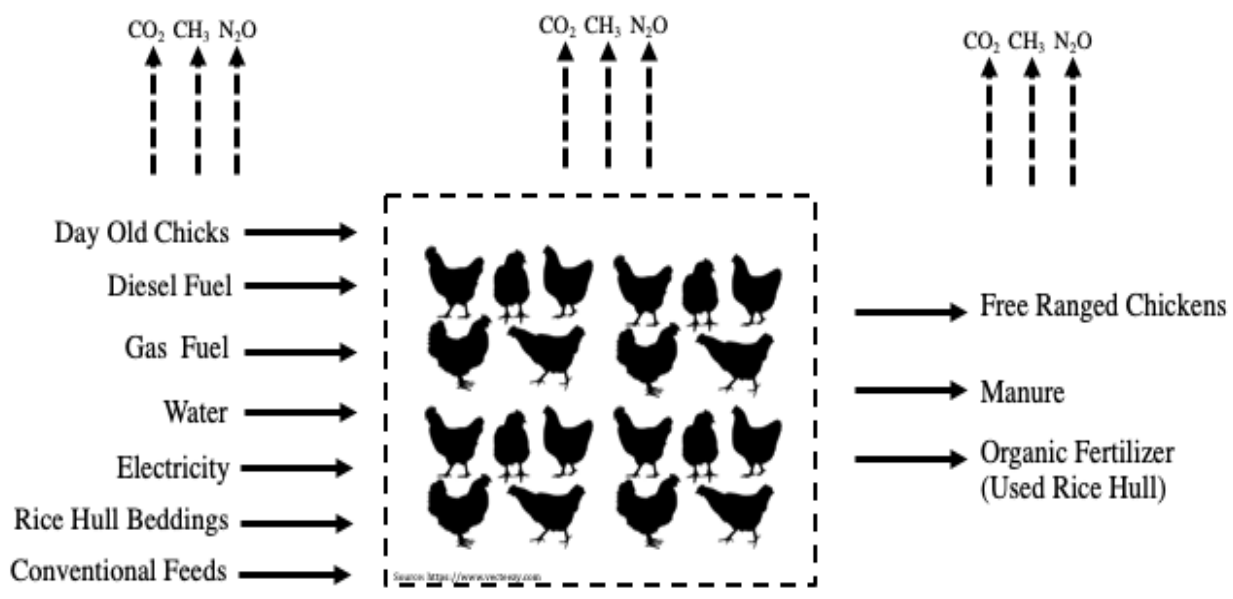

Fig. 2: Gate to gate system boundary of backyard chicken farm.

Table 3: Life Cycle Inventory and GHG Emissions per 1,000 birds of current set-up.

\begin{tabular}{|c|c|c|c|c|c|c|}
\hline \multirow[t]{2}{*}{ Inputs } & \multirow[t]{2}{*}{ Unit } & \multirow[t]{2}{*}{ Quantity } & \multicolumn{4}{|c|}{ GWP in GWP in $\mathrm{kg} \mathrm{CO}_{2}$-eq/unit } \\
\hline & & & $\mathrm{CO}_{2}$ & $\mathrm{CH}_{4}$ & $\mathrm{~N}_{2} \mathrm{O}$ & Total \\
\hline Tranpo-Diesel & $\mathrm{L}$ & 55.10 & 129.375 & 0.004 & 0.018 & 129.396 \\
\hline Transpo-Gasoline & $\mathrm{L}$ & 67.50 & 156.533 & 0.002 & 0.002 & 156.536 \\
\hline Electricity & $\mathrm{kWh}$ & 726.00 & 437.778 & - & - & 437.778 \\
\hline Water & $\mathrm{m}^{3}$ & 47.50 & 41.325 & - & - & 41.325 \\
\hline Bedding & $\mathrm{kg}$ & 625.00 & 609.375 & 4.125 & 6.519 & 620.019 \\
\hline Feed & $\mathrm{kg} \mathrm{CW}$ & $1,011.75$ & $3,433.408$ & - & $1,349.522$ & $4,782.929$ \\
\hline Manure & $\mathrm{kg} \mathrm{CW}$ & $1,011.75$ & - & 287.462 & $3,365.168$ & $3,652.630$ \\
\hline Total & & & $4,807.793$ & 291.592 & $4,721.229$ & $9,820.614$ \\
\hline
\end{tabular}


9,820.614 $\mathrm{kg} \mathrm{CO}_{2}$ eq. Among GHG gasses, carbon dioxide contributed the highest at $48.96 \%$ followed by nitrogen oxide at $48.07 \%$. Carbon dioxide is generated much from the use of conventional feeds, followed by use of electricity and fuels. As discussed in the inventory analysis, there is limited transportation activities, with most of it coming from the mobility of the caretaker for feeding and pasturing. Also, the use of rice hull beddings is limited to the brooding area since the birds are allowed to range after 28 days. For nitrogen dioxide, it is basically driven by the use of conventional feeds and manure. The methane gas has minimal impact given that it has limited transportation activities, thereby, its major contributor is just manure.

The Gleam-I data does not include emissions from direct and indirect uses for backyard chickens. Thereby, comparison can be done with feed and manure related components only. The farm's 8,345.56 $\mathrm{kg} \mathrm{CO}_{2}$ eq/1,000 birds is much higher than Philippine's baseline average of 5,675.92 and East Asia and Southeast Asia regional average of 6,546.02 $\mathrm{kg} \mathrm{CO}$ eq/ 1,000 birds. Versus neighbouring countries, it is still much higher with Malaysia's 6,019.91, Thailand's 5,433.10 and Indonesia's 5,089.10.

The high GWP per 1,000 birds in this system can be de directly associated with the use of commercial feeds and the yield per cycle. Hence, the area for improvements in this system is to use alternative feeds with lower environmental impact as well as improve the average yield to distribute the impacts of the fixed inputs.
Global warming potential impact of AZM inclusion: The inclusion of Azolla Pinnata has no significant potential adverse effect in global warming potential on various forms as demonstrated on the studies (Kimani et al. 2018) on a rice paddy in Japan; (Xu et al. 2017) on double rice cropping system in southern China; (Jumadi et al. 2014) on the growth of upland Kangkong in silt loam soil in Indonesia. In providing a regular source of the floating fern, the farm uses a 2 sqm improvised water tub, wherein the Azolla Pinnata is propagated and harvested daily when needed. With the propagation method and application, there is no quantifiable impact from Azolla Pinnata to be considered.

The recommended 50\% replacement of commercial feeds cut down the volume of feeds by half. This new feed mix ratio was inputted to the Gleam-I system, which changed the GHG profiles of feed and manure. As given in Table 4, the total GWP decreased to 7,024.83 $\mathrm{kg} \mathrm{CO}_{2}$ eq/1,000 bird. The 50\% AZM resulted in a reduction of $\mathrm{CO}_{2}$ by $35 \% ; \mathrm{N}_{2} \mathrm{O}$ by $22.32 \%, \mathrm{CH}_{4}$ by $4.74 \%$, and total GWP by $28.47 \%$, as shown in Fig. 3 .

In terms of relative contribution in Fig. 4 , feeds decreased its share by $14.95 \%$ while manure increased by $9.3 \%$, beddings by $2.51 \%$, electricity by $1.77 \%$ and less than $1 \%$ for diesel and gasoline respectively.

Aside from the decrease in GWP, it is worth noting that the reduction in commercial feeds and replacement with AZM will also have a significant effect on production costs. Hence, the 50\% AZM inclusion provides both environmental and economic impacts of this studied farm.

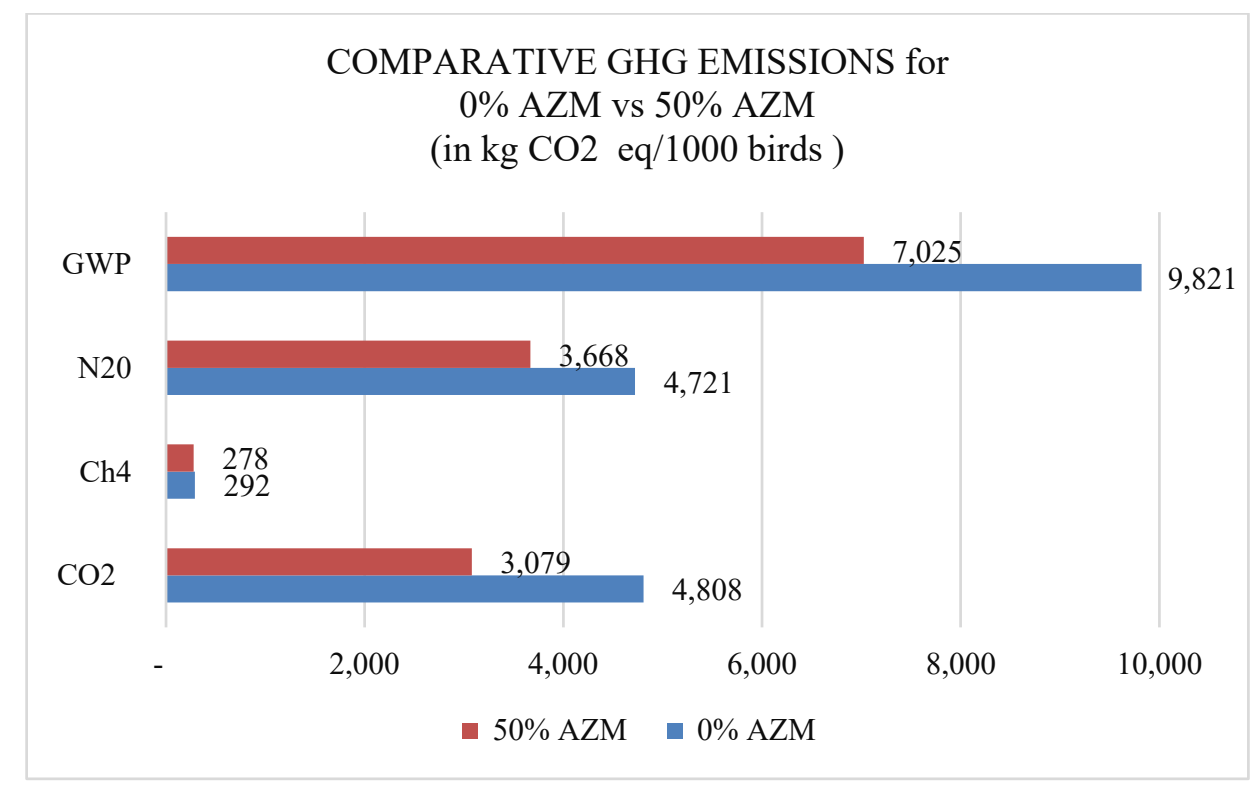

Fig. 3: Comparative GHG emissions for 0\% AZM versus 50\% AZM. 


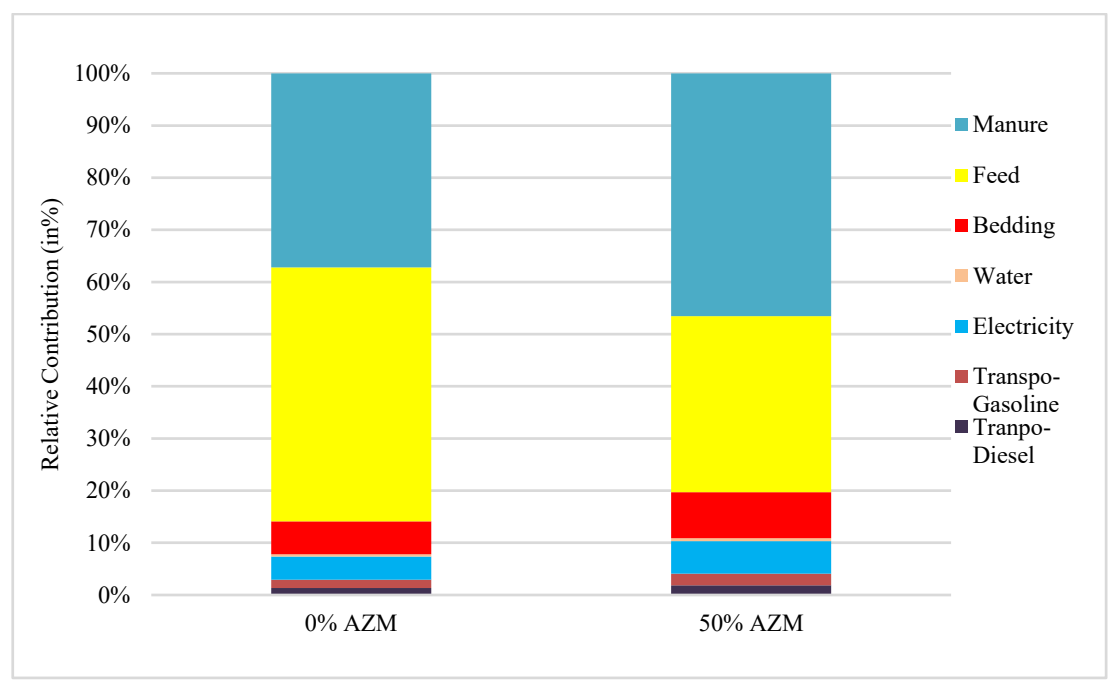

Fig. 4: Relative Contribution of Inputs to GWP.

Table 4: Life Cycle Inventory and GHG Emissions per 1,000 birds with 50\% AZM inclusion.

\begin{tabular}{|c|c|c|c|c|c|c|}
\hline \multirow[t]{2}{*}{ Inputs } & \multirow[t]{2}{*}{ Unit } & \multirow[t]{2}{*}{ Quantity } & \multicolumn{4}{|c|}{ GWP in GWP in $\mathrm{kg} \mathrm{CO}_{2}$-eq/unit } \\
\hline & & & $\mathrm{CO}_{2}$ & $\mathrm{CH}_{4}$ & $\mathrm{~N}_{2} \mathrm{O}$ & Total \\
\hline Tranpo-Diesel & $\mathrm{L}$ & 55.10 & 2.3480 & 0.0001 & 0.0003 & 129.3964 \\
\hline Transpo-Gasoline & $\mathrm{L}$ & 67.50 & 2.3190 & 0.0000 & 0.0000 & 156.5364 \\
\hline Electricity & $\mathrm{kWh}$ & 726.00 & 0.6030 & - & - & 437.7780 \\
\hline Water & $\mathrm{m}^{3}$ & 47.50 & 0.8700 & - & - & 41.3250 \\
\hline Bedding & $\mathrm{kg}$ & 625.00 & 0.9750 & 0.0066 & 0.0104 & 620.0188 \\
\hline Feed & $\mathrm{kg} \mathrm{CW}$ & $1,011.75$ & 1.6853 & & 0.6585 & $2,371.3025$ \\
\hline Manure & $\mathrm{kg} \mathrm{CW}$ & $1,011.75$ & & 0.2704 & 2.9601 & $3,268.4761$ \\
\hline Total & & & $3,079.491$ & 277.757 & $3,667.586$ & $7,024.8331$ \\
\hline
\end{tabular}

\section{CONCLUSION AND PERSPECTIVES}

The studied farm has a GWP impact of 9,820.614 $\mathrm{kg} \mathrm{CO}_{2}^{-}$ eq./1,000 birds with its current set-up using the commercial feed to Dominant CZ breed in backyard free-range rearing system. With the recommended inclusion of 50\% AZM, GWP reduced to 7,024.83. This showed favourable results since there were reductions of $\mathrm{CO}_{2}$ by $35 \% ; \mathrm{N}_{2} \mathrm{O}$ by $22.32 \%$, $\mathrm{CH}_{4}$ by $4.74 \%$. The gross effect of this reduction of conventional feeds is a climate change mitigation equivalent $28.47 \%$ of GWP kg CO 2 -eq./1,000 birds. The environmental evaluation of AZM showed that the floating fern has favourable benefits, especially in the countryside. Moreover, potential savings can be generated from the $50 \%$ decrease in commercial feeds. The impacts indicate that Azolla Pinnata can be a cost-effective and sustainable feedstuff in backyard chicken rearing system especially that it requires simple propagation method. The environmental impact and savings can encourage more livelihood activities in rural.

\section{ACKNOWLEDGEMENT}

The authors acknowledge the Engineering Research and Development Technology in the Philippines for the support and the farm owner Mr Paul Duran for the assistance in the conduct of the study.

\section{REFERENCES}

Alalade, O. A., Iyayi, E. A. and Alalade, T. O. 2007. The nutritive value of Azolla (Azolla pinnata) meal in diets for growing pullets and subsequent effect on laying performance. The Journal of Poultry Science, 44: 273-277. https://doi.org/10.2141/jpsa.44.273

Bare, J. 2012. Tool for the Reduction and Assessment of Chemical and Other Environmental Impacts. Retrieved July 10, 2019, from https:// nepis.epa.gov/Adobe/PDF/P100HN53.pdf

Chang, H. C. 2007. Analysis of the Philippine chicken industry : Commercial versus backyard sectors. Asian Journal of Agricultural Development, 3(1): 1-16.

Climate Change Commission. 2011. National Climate Change Action Plan 2011-2018. Retrieved July 2, 2019, from http://climate.emb.gov.ph/ wp-content/uploads/2016/06/NCCAP-1.pdf 
DOE. 2017. 2015-2017 National Grid Emission Factor (NGEF). Retrieved August 1, 2019, from https://www.doe.gov.ph/national-grid-emission-factor-ngef

Dozier, W. A., Kidd, M. T. and Corzo, A. 2008. Dietary amino acid responses of broiler chickens. Journal of Applied Poultry Research, 17(1): 157-167. https://doi.org/10.3382/japr.2007-00071

Engineering Tool Box. 2009. Combustion from Fuels - Carbon Dioxide Emission. Retrieved March 5, 2019, from https://www.engineeringtoolbox.com/co2- emission-fuels-d_1085.html [

EPA. 2017. Understanding Global Warming Potentials. Retrieved March 5, 2019, from https://www.epa.gov/ghgemissions/understanding-global-warming-potentials

FAO, 2017. Global Livestock Environmental Assessment Model (GLEAM-i). Retrieved July 5, 2019, from www.fao.org/gleam/en/

Griffiths-Sattenspiel, B. and Wilson, W. 2009. The Carbon Footprint of Water. Retrieved July 10, 2019, from https://www.rivernetwork.org/ resource/the-carbon-footprint-of-water/

Jaturasitha, S., Vearasilp, T., Leotaragul, A., Phongphaew, A., Apichartsrungkoon, N., Simasathitkul, N. and ter Meulen, U. 2002. A comparative study of thai native chicken and broiler on productive performance, carcass and meat Quality. In: Conference on International Agricultural Research for Development. Witzenhausen. Retrieved from http://www. tropentag.de/2002/abstracts/full/213.pdf

Jensen, A. A. 2008. SETAC Europe LCA steering committee-the early years. International Journal of Life Cycle Assessment, 1: 1-6. https:// doi.org/10.1065/lca2007.12.371

Jumadi, O., Hiola, S. F., Hala, Y. and Norton, J. 2014. Influence of Azolla ( Azolla microphylla Kaulf .) compost on biogenic gas production , inorganic nitrogen and growth of upland kangkong ( Ipomoea aquatica Forsk .) in a silt loam soil Influence of Azolla (Azolla microphylla Kaulf) compost on biogenic. Soil Science and Plant Nutrition, 60(5): 722-730. https://doi.org/10.1080/00380768.2014.942879

Kimani, S. M., Cheng, W., Kanno, T., Nguyen-sy, T., Abe, R., Oo, A. Z. and Sudo, S. 2018. Azolla cover significantly decreased $\mathrm{CH}_{4}$ but not $\mathrm{N}_{2} \mathrm{O}$ emissions from flooding rice paddy to atmosphere. Soil Science and Plant Nutrition, 64(1): 68-76. https://doi.org/10.1080/00380768. 2017.1399775

MacLeod, M., Gerber, P., Mottet, A., Tempio, G., Falcucci, A., Opio, C. and Steinfeld, H. 2013. Greenhouse gas emissions from pig and chicken supply chains-A global life cycle assessment. Rome. Retrieved August 1,2019 from http://www.fao.org/3/i3460e/i3460e.pdf

Mananghaya, K. M. V. 2017. Enhancing your pasture for sustainable native chicken production “. Retrieved August 1, 2019, from http://www. pcaarrd.dost.gov.ph/home/portal/index.php/quick-information-dispatch/2866-enhancing-your-pasture-for-sustainable-native-chicken-production

Namra, M. M. M., Hataba, N. A. and Wahed, H. M. A. 2010. The productive performance of growing fayoumi chicks fed restricted diets supplemented with free fresh Azolla. Egypt Poultry Science, 30(III): 747-762.

Padhi, M. K. 2016. Importance of indigenous breeds of chicken for rural economy and their improvements for higher production performance. Scientifica, 2016, 1-9. https://doi.org/10.1155/2016/2604685

Pillai, P., Premalatha, S. and Rajamony, S. 2005. Azolla: a sustainable feed for livestock. Leisa Magazine, 4: 26-27. Retrieved from http:// www.eriksjodin.net/projects/ theazollacookingandcultivationproject/ research/Azolla, a sustainable feed for livestock.pdf

PinoyBisnis.com. 2010. Raising Solraya's sunshine chickens. Retrieved March 5, 2019, from https://www.pinoybisnes.com/livestock-business/ raising-solraya-sunshine-chickens/

PSA. 2018. Chicken Industry Performance Reports 2011-2017. Retrieved July 7, 2019, from https://psa.gov.ph/content/chicken-situation-report

Rascio, N. and La Rocca, N. 2008. Biological Nitrogen Fixation. Encyclopedia of Ecology, Five-Volume Set, 412-419. https://doi.org/10.1016/ B978-008045405-4.00273-1

Roxas, N. P. 2000. Growth performance of Philippine native and broiler. Philippine J. Vet Animal Science, 26: 185-196.

Siacor, F. D. C. 2019. Meat Chemical Composition Analysis of Azolla Pinnata.Unpublished Data.

Sison, J. A. 2014. Feed use estimation-data, methodology and gaps the case of the Philippines. Metro Manila. Retrieved from http://www. amis-outlook.org/fileadmin/user_upload/amis/docs/resources/3c Feed use estimation - Data, methodologies and gaps (Philippines) September 2014.pdf

Thieme, O., Sonaiya, E. B., Rota, A., Alders, R., Saleque, M. A., De' Besi, G. 2014. Family poultry development - issues, opportunities and constraints. Animal Production and Health Working Paper. No. 12. Rome.

USAID. 2016. Greenhouse Gas Emissions in the Philippines. Retrieved July 2, 2019, from https://www.climatelinks.org/resources/greenhouse-gas-emissions-factsheet-philippines

Wong, J., de Bruyn, J., Bagnol, B., Grieve, H., Li, M., Pym, R. and Alders, R. G. 2017. Small-scale poultry and food security in resource-poor settings: A review. Global Food Security, 15: 43-52.

Xu, H., Zhu, B., Liu, J., Li, D., Yang, Y. and Zhang, K. 2017. Azolla planting reduces methane emission and nitrogen fertilizer application in double rice cropping system in southern China. Agron. Sustain. Dev., 37(29): 1-9. https://doi.org/10.1007/s13593-017-0440-z 